\title{
Penegakan Hukum terhadap Pelanggaran Angkutan Jalan dalam Berlalu Lintas di Kota Ternate
}

\author{
Fahria \\ Fakultas Hukum Universitas Khairun. E-mail: fahriasiradju@gmail.com
}

Faisal

Fakultas Hukum Universitas Khairun.E-mail: faisaldjabid5@gmail.com

\begin{abstract}
:
The level of traffic safety and the level of compliance of the people of Ternate City, against traffic laws and legislation is very alarming, this is if strategic steps are not taken, namely creating law enforcement that is more oriented to efforts to change the traffic situation in realizing the security order situation and the smooth flow of traffic from the aspects of drivers, vehicles, roads and the environment in order to increase the level of safety and increase legal compliance and public awareness of traffic, it will cause loss of property and loss of life. To be able to provide a deterrent effect to motorists who violate traffic laws, efforts must be taken from law enforcement officials both in administrative and criminal proceedings.
\end{abstract}

Keywords: Law Enforcement, Traffic, Safety

\section{PENDAHULUAN}

Penegakan hukum dalam rangka meningkatkan keselamatan lalu lintas harus dilakukan secara konsisten dan konperehensif mengingat lalu lintas dewasa ini telah mengalami kemajuan yang tidak seimbang dengan aspek kebutuhan perkembangan sektor lainnya, sebagai gambaran pertambahan jumlah penduduk, luas jalan dan volume jalan, pengembangan lingkungan seperti; pertokoan dan industri, yang mengakibatkan fungsi lalu lintas akan mengalami mobilitas yang tinggi.

Pemerintah dan kepolisian bertanggung jawab atas terjaminnya keselamatan Lalu Lintas dan Angkutan Jalan (LLAJ), tetapi tanggung jawab pemerintah hanya terorientasi seperti yang telah disebutkan dalam Undang-Undang Nomor 22 Tahun 2009 Tentang Lalu Lintas dan Angkutan Jalan (UU LLAJ) Pasal 203 ayat (1) yaitu, pemerintah bertanggung jawab atas terjaminnya lalu lintas dan angkutan jalan. Dan ayat (2), untuk menjamin keselamatan lalu lintas dan angkutan jalan sebagaimana dimaksud pada ayat (1), diterapkan rencana umum nasional keselamatan lalu lintas dan angkutan jalan, yang meliputi :

a. penyusunan program nasional kegiatan keselamatan lalu lintas dan angkutan jalan.

b. penyediaan dan pemeliharaan fasilitas dan perlengkapan keselamatan lalu lintas dan angkutan jalan

c. pengkajian masalah keselamatan lalu lintas dan angkutan jalan.

Sedangkan Kepolisian bertanggung jawab dalam keselamatan LLAJ adalah lebih khusus pada registrasi, dan identifikasi kendaraan bermotor serta menjamin penegakan supremasi hukum 
dalam bidang lalu lintas, seperti yang telah disebutkan UU LLAJ Pasal 7 ayat (2e) yaitu "urusan pemerintahan dibidang registrasi dan identifikasi kendaraan bermotor dan pengemudi, penegakan hukum, operasional manajemen, dan rekayasa lalu lintas, serta pendidikan lalu lintas, oleh Kepolisian Nagara Republik Indonesia". ${ }^{1}$ Dan Pasal 200 ayat (1) yang menyebutkan "Kepolisian Negara Republik Indonesia bertanggung jawab atas terselenggaranya kegiatan dalam mewujudkan dan memelihara keamanan lalu lintas dan angkutan jalan. ${ }^{2}$ Yang merupakan spesifikasi dari Undang-Undang Nomor 2 Tahun 2002 Tentang Kepolisian Negara Republik Indonesia yang menyebutkan tugas pokok kepolisian dalam Pasal 5 ayat (1) "Kepolisian Negara Republik Indonesia merupakan alat negara yang berperan dalam memelihara kemanan dan ketertiban masyarakat, menegakkan hukum serta memberikan perlindungan, pengayoman dan pelayanan kepada masyarakat dalam rangka terpeliharanaya keamanan dalam negeri". ${ }^{3}$

Kasat Lantas Polres Ternate, AKP Andreas Adi Febrianto, menjelaskan bahwa tujuan dari upaya penegakan hukum yang dilakukan oleh SAT LANTAS Polres Ternate adalah untuk menjamin adanya keselamatan bagi pengguna lalu lintas, tetapi dengan terbatasnya sumber daya yang dimiliki oleh SAT LANTAS dan masih kurangnya prosenil SAT LANTAS, sehingga tidak dapat mengatur dan memantau semua titik-titik jalan yang ada, maka harus dibutuhkan koordinasi terpadu terutama kesadaran hukum dari masyarakat untuk mematuhi semua peraturan lalu lintas agar terhindar dari kecelakaan lalu lintas (lakalantas). Kemudian faktor-faktor sebagai penyebab terjadinya kecelakaan yaitu faktor human error (kelalaian manusia) antara lain, tidak disiplin (melanggar peraturan), emosional, daya konsentrasi kurang, ngantuk. mabuk (pengaruh minuman keras). Serta faktor kendaraan yaitu, tidak laik jalan, ban pecah, rem dan lampu tidak berfungsi, melebihi muatan, bukan peruntukan. Kemudian faktor jalan dan lingkungan yaitu; jalan sempit, bergelombang, tikungan, tanjakan dan menurun, dan faktor cuaca anatara lain, hujan serta licin, kabut. ${ }^{4}$

Kurang disiplin dan tidak patuhnya para pemakai jalan menunjukkan masih kurangnya kesadaran hukum dari para pengguna jalan itu sendiri dalam mematuhi peraturan lalu lintas. Kesadaran hukum masyarakat menyangkut faktor-faktor apakah suatu ketentuan hukum diketahui, dimengerti, ditaati dan dihargai. Apabila masyarakat hanya mengetahui adanya suatu ketentuan hukum saja, maka taraf kesadaran hukumnya lebih rendah daripada apabila mereka memahaminya dan seterusnya. Jadi kesadaran hukum tumbuh ketika suatu aturan itu tidak hanya sekedar diketahui dan dimengerti, tetapi juga harus ditaati dan dihargai.

Pemahaman masyarakat Kota Ternate akan kesadaran lalu lintas demi menjamin keselamatan lalu lintas masih sangat minim hal ini terlihat dari ketidak hati-hatian masyarakat dalam berkendaraan ataupun pejalan kaki yang terkadang mengabaikan aturan lalu lintas, apabila terjadinya lakalantas itu akibat dari ketidak disiplinan berlalu lintas. Dilihat dari kondisi wilayah Kota Ternate yang hanya mempunyai luas daratan $250,85 \mathrm{~km}^{2}$. Maka untuk transportasi khususnya angkutan darat dengan tingkat kendaraan yang padat dan tidak seimbang dengan penyiapan jalan protokol akan sangat berpengaruh terhadap penumpukan mobilisasi transportasi, apalagi ditambah dengan kondisi jalan raya kurang baik, pengadaan rambu-rambu lalu lintas dijalur rawan kecelakaan yang belum maksimal maka akan lebih rentan timbulnya kecelakaan selain dari segi kelalaian pengendara.

Bagian SAT LANTAS Polres Ternate, telah mengupayakan tugas dan fungsi kepolisian seperti yang telah diamanatkan oleh UU LLAJ, dan UU No 2 Tahun 2002. Berdasarkan hasil

\footnotetext{
${ }^{1}$ Tim Redaksi Pustaka Yustisia, 2010, UU No. 22 Tahun 2009 Tentang lalu Lintas dan Angkutan Jalan, Jakarta. Hlm 11.

2 Ibid. Hlm 104.

${ }^{3}$ Surat Keputusan Kapolri No. Pol. : Skep/180/III/2006. Tentang Buku Pedoman Pelaksanaan Tugas Bintara Polri di Lapangan. Hlm 38.

${ }^{4}$ Kasat Lantas Polres Ternate, AKP Andreas Adi Febrianto, tanggal 28 Februari 2019.
} 
pantauan penulis di Polres Ternate bahwa setiap selesai apel pagi antara jam 06.30 s.d 08.00 seluruh Polantas diinstruksikan oleh Kepala Polisi Resor (Kapolres) untuk turun kejalan yang mempunyai tingkat mobilitas kendaraan yang cukup tinggi, hal ini disebabkan karena akan ada banyak aktifitas masyarakat yang menggunakan kendaraan. Upaya ini dilakukan untuk mengatur keamanan jalan agar kendaraan dapat tertib dan teratur sehingga keselamatan penggunan jalan dalam berlalu lintas dapat terjamin. Disamping itu untuk melaksanakan tugas harian berdasarkan UU LLAJ dan UU No. 2 Tahun 2002 Kasat Lantas (Kepala Satuan Lalu Lintas) atas nama Kapolres mengeluarkan Surat Perintah (Sprin) untuk melaksanakan tugas pokok sehari-hari dalam wilayah hukum Polres Ternate, supaya mengantisipasi daerah rawan kecelakaan, dan rawan macet. Surat Perintah ini berlaku selama 31 hari dan berlaku sejak tanggal satu, setiap Sprin yang dikeluarkan terdiri dari 20 anggota SAT LANTAS. Untuk pengaturan tehnis jumlah anggota yang telah diberi sprin dibagi menjadi 3 (tiga) shif dengan memakai sistim roling, dan penunjukan tempat tugas dari masing-masing anggota SAT LANTAS berdasarkan Sprin tergantung dari perintah Komandan Jaga. ${ }^{5}$

Disamping itu langkah-langkah perventif telah dilakukan oleh Polres Ternate, dalam hal terwujudnya etika berlalu lintas dan budaya bangsa (just culture) melalui upaya pembinaan, pemberian bimbingan, dan pendidikan berlalu lintas sejak usia dini yang telah dilaksanakan melalui program yang berkesinambungan, antara lain dari segi edukasi memberikan penyuluhan dari Sekolah Dasar sampai Sekolah Menengah Atas (SMA) untuk mentaati peraturan lalu lintas dan pejalan kaki yang harus menggunakan trotor, mengemudi tidak dalam keadaan mabuk, tidak mengantuk dan lainnya yang dapat mengakibatkan kelalaian dalam berkendaraan karena hal ini akan berpotensi terjadinya kecelakaan. Dari segi sosialisasi etika berlalu lintas Polres Ternate telah memberikan pemahaman tentang berlalu lintas yang baik demi menghindari kecelakaan antara lain, melalui reklame seperti spanduk yang sering di pajang di pusat Kota maupun di sekitar jalan yang rawan akan kecelakaan.

\section{KAJIAN KEPUSTAKAAN}

\section{A. Tinjauan Umum Undang-undang Nomor 22 Tahun 2009 Tentang Lalu Lintas dan Angkutan Jalan.}

Lalu lintas dan Angkutan Jalan (LLAJ) mempunyai peranan penting dalam mendukung pembangunan dan integrasi nasional sebagai bagian dari upaya memajukan kesejahteraan umum seperti yang diamanatkan oleh pembukaan Undang-Undang Dasar 1945. LLAJ sebagai bagian dari sistem transportasi nasional harus dikembangkan potensi dan perannya untuk mewujudkan keamanan, keselamatan, ketertiban dan kelancaran berlalu lintas dan angkutan jalan dalam rangka mendukung pembangunan ekonomi dan pengembangan wilayah, untuk dibutuhkan suatu regulasi normatif untuk mengatur semua itu.

Undang-undang LLAJ harus ditegakan secara konsisten oleh pihak yang berwenang dan berlaku untuk semua kalangan masyarakat. Menurut Soerjono Soekanto menyebutkan bahwa, UU dalam arti materiel harus mencakup :

a. Peraturan pusat yang berlaku untuk semua warga negara atau suatu golongan tertentu saja maupun yang berlaku umum disebahagian wilayah negara.

b. Peraturan setempat yang hanya berlaku di suatu tempat atau daerah saja. ${ }^{6}$

Pengertian lalu lintas menurut Poerwadarminta dalam Kamus Umum Besar Bahasa Indonesia diartikan sebagai perhubungan antara sebuah tempat, ${ }^{7}$ menurut undang-undang LLAJ dalam Pasal 1 angka (2) menyebutkan bahwa lalu lintas adalah gerak kendaraan dan orang diruang

\footnotetext{
${ }^{5}$ Surat Perintah Nomor : Sprin / 132 / III / 2013 / Lantas

${ }^{6}$ Soerjono Soekanto, 2011. Faktor-Faktor Yang Mempengaruhi Penegakan Hukum, Cet. Kesepuluh, Raja Grafindo Persada, Jakarta. HIm 3.

7 Poerwadarminta,1987. Kamus Umum Besar Bahasa Indonesia,Balai Pustaka, Jakarta. Hal 317.
} 
de Jure; Jurnal Ilmiah Ilmu Hukum $\bigcirc$ Vol. 1 No. 1 Desember (2019) : 16-29

lalu lintas jalan. lalu lintas dapat diartikan sebagai hilir mudiknya manusia dan atau barangdari suatu tempat ketempat lainnya. ${ }^{8}$ Sedangkan pengertian angkutan menurut Poerwadarminta dalam Kamus Umum Besar Bahasa Indonesia diartikan pembawaan orang atau barang. ${ }^{9}$ Dan menurut undang-undang LLAJ menyebutkan dalam Pasal 1 angka (3) menyebutkan angkutan adalah perpindahan orang dan/atau barang dari suatu tempat ke tempat lain dengan menggunakan diruang lalu lintas jalan. ${ }^{10}$ jadi pengertian Angkutan Jalan dalam Pasal 1 angka (1) menyebutkan lalu lintas angkutan jalan adalah satu kesatuan sistem yang terdiri atas lalu lintas, angkutan jalan, jaringan lalu lintas dan angkutan jalan, prasarana lalu lintas dan angkutan jalan, kendaraan, pengemudi, pengguna jalan, serta pengelolaannya. ${ }^{11}$

Menurut Soerjono Soekanto, penegakan hukum (law enforcement) menghendaki empat syarat, yaitu : adanya aturan, adanya lembaga yang akan menjalankan peraturan itu, fasilitas untuk mendukung pelaksanaan peraturan itu, adanya kesadaran hukum dari masyarakat yang terkena peraturan itu. ${ }^{12}$ Pengertian penegakan hukum dapat dirumuskan sebagai usaha melaksanakan hukum sebagaimana mestinya, mengawasi pelaksanaannya agar tidak terjadi pelanggaran dan jika terjadi pelanggaran maka ada usaha lain untuk memulihkan hukum yang dilanggar agar dapat ditegakkan kembali. Penegakan hukum adalah kegiatan menyelaraskan hubungan nilai-nilai yang terjabarkan di dalam kaidah-kaidah yang mantap dan sikap tindakan sebagai rangkaian nilai tahap akhir, untuk menciptakan, memelihara, dan mempertahankan kedamaian pergaulan hidup. ${ }^{13}$

Keseluruhan penyelenggaraan lalu lintas Kepolisian Negara Republik Indonesia telah membentuk divisi khusus yang disebut sebagai Polisi Lalu Lintas (Polantas) yang merupakan unsur pelaksana yang bertugas menyelenggarakan tugas kepolisian mencakup penjagaan, pengaturan, pengawalan dan patrol, pendidikan masyarakat dan rekayasa lalu lintas, registrasi dan identifikasi pengemudi/kendaraan bermotor, penyidikan kecelakaan lalu lintas dan penegakan hukum dalam bidang lalu lintas, guna memelihara kemanan, ketertiban dan kelancaran lalu lalu lintas, Sesuai dengan maksud Pasal 7 ayat (2) e undang-undang LLAJ. ${ }^{14}$

Selain pidana penjara, kurungan, atau denda, pelaku tindak pidana lalu lintas dapat dijatuhi pidana tambahan berupa pencabutan Surat Izin Mengemudi atau ganti kerugian yang diakibatkan oleh tindak pidana lalu lintas (lihat Pasal 314 UU LLAJ). ${ }^{15} \mathrm{Jadi}$, atas kecelakaan lalu lintas yang mengakibatkan kerugian materi namun tidak ada korban jiwa, perusahaan angkutan umum dapat dikenakan sanksi penggantian kerugian berdasarkan kerugian yang nyata-nyata dialami sebagaimana telah kami uraikan di atas, atau sanksi administratif sesuai peraturan perundang-undangan yang berlaku.

Kesadaran merupakan perilaku yang hidup dalam masyarakat untuk mengetahui atau mengerti dan taat pada aturan perundang-undangan yang berlaku seperti yang dijelaskan oleh Flyn yang dikutip oleh Djahiri menyebutkan; sadar akan nilai atau value meliputi lima hal kesadaran akan adanya sistem nilai, mengikuti sistem nilai tersebut, keharusan membina dan meningkatkan sistem nilai tersebut, sadar untuk mencobanya dan membukanya sebagai suatu sistem nilai yang baku. ${ }^{16}$

\footnotetext{
${ }^{8}$ Tim Yustia, Oc. Cit. Hlm 3.

${ }^{9}$ Poerwadarminta, Oc.Cit. Hlm 318.

${ }^{10}$ Tim Yustia, Oc. Cit. Hlm 3.

${ }^{11}$ Ibid. Hlm 1.

12 Soerjono Soekanto, 1987, Pendekatan Sosiologi Terhadap Hukum, Jakarta, Bina Aksara.. Hlm. 9.

${ }^{13}$ Maxtry Parante https://media.neliti.com/media/publications/115374-ID-peranan-kepolisian-lalu-lintas-dalampen.pdf

${ }^{14}$ Tim Yustia, Oc. Cit. Hal 7.

${ }^{15}$ Tim Yustia, Ibid. Hlm 152-154.

${ }^{16}$ Kosasih Djahiri, 1985. Strategi Pengajaran Afektif Nilai-Nilai Moral, ISIP, Bandung. hal 24.
} 
Mengacu kepada pendapat diatas dapat ditarik kesimpulan secara umum bahwa kesadaran merupakan suatu kesiapan diri untuk melakukan atau tidak melakukan sesuatu, dengan didasari atas pengertian, pemahaman, penghayatan dan pertimbangan nalar dan moral dengan disertai kebebasan sehingga dapat mempertanggungjawabkan secara sadar, dan kesadaran ini dapat diperoleh dengan cara belajar untuk melihat sikap dan perilaku sehari-hari. Dengan demikian kesadaran hukum adalah suatu proses kesadaran bahwa hukum itu melindungi kepentingan manusia sehingga harus dipatuhi dan dilaksanakan walaupun sifatnya memaksa jika melanggarnya akan dikenakan sanksi sebagai efek jera. Kesadaran hukum adalah sumber segala hukum artinya kesadaran hukum ada pada setiap manusia agar kepentingan tadi dapat terlindungi, seperti yang dijelaskan oleh Paul Scholten yang dikutip oleh Sudikno Mertokusumo, kesadaran hukum yaitu kesadaran yang ada pada setiap manusia tentang apa hukum itu, apa seharusnya hukum itu, suatu kategori tertentu dari hidup kejiwaan kita dengan mata kita membedakan antara hukum dengan tidak hukum, antara seyogjanya dilakukan atau tidak dilakukan. ${ }^{17}$

Kesadaran hukum yang diharapkan adalah tentang nilai masyarakat yang menyangkut tentang fungsi hukum dan bukan penjelasan hukum tentang kejadian-kejadian yang kongkrit dalam masyarakat. Berdasarkan pendapat diatas dapat ditarik kesimpulan bahwa kesadaran merupakan suatu keyakinan atau kesadaran yang ada di dalam setiap diri seorang individu berupa nilai-nilai yang terintegrasi dalam dirinya terhadap hukum yang ada, yang kemudian diwujudkan melalui tindakan dalam bentuk kepatuhan dan ketidak patuhan terhadap hukum itu, yang berkaitan dengan tingkat kesadarannya. ${ }^{18}$ Hal ini karena kurangnya sosialisasi, komunikasi hukum sehingga mengakibatkan pemahaman yang kurang merata terhadap ketentuan hukum yang berlaku. Untuk mengatasinya diperlukan mediasi, sosialisasi seperti penyuluhan hukum, seminar, yang dianggap dapat memperluas pemahaman masyarakat tentang hukum. Dalam hal ini Ahmad Sanusi juga berpendapat bahwa sebagai indikator tentang tinggi rendahnya tingkat kesadaran hukum masyarakat itu dapat dapat diperhatikan disatu pihak sudut ketaatannya pada peraturan hukum dan dilain pihak dari sudut banyaknya pelanggaran hukum yang dilakukan oleh anggota masyarakat yang bersangkutan. ${ }^{19}$

\section{METODE PENELITIAN}

Berdasarkan rumusan masalah dan tujuan yang ingin dicapai dalam penelitian ini yakni kajian hukum tentang pelanggaran lalu lintas maka jenis penelitian yang digunakan adalah penelitian normative-empiris, dengan melakukan pencegahan dan penindakan dengan melihat berbagai norma hukum yang sudah ada yang dikehendaki, bukan semata mempelajari norma hukum yang berlaku, tetapi juga melihat dari berbagai problem yang terjadi dengan berbagai pendekatan yang ada. Dengan demikian maka Kepolisian dalam hal ini Kasat Lantas serta Dinas Perhubungan Kota, berusaha melakukan suatu tindakan pencegahan maupun penindakan untuk menghidari terjadinya kecelakaan dan proses hukum serta kerugian materil bagi pengendara di Kota Ternate.

Pendekatan yang digunakan dalam penelitian ini, yaitu pendekatan perundang-undangan, dan berbagai kebijakan yang di buat. Dalam konteks ini, ketentuan-ketentuan yang akan ditelaah dan dikaji adalah beberapa instrumen hukum nasional dan kebijakan daerah, ${ }^{20}$ sedangkan untuk menganalisis penulis menggunakan pendekatan konseptual (conceptual approach) dan pendekatan kasus (case approach), (Peter Mahmud Marzuki, 2010:137).

\footnotetext{
${ }^{17}$ Sudikno Mertokusumo, 1984, Bunga Rampai Ilmu Hukum, Liberty, Yogyakarta. Hlm 2

18 Soerjono Soekanto, 1982. Suatu Tinjauan Sosiologi Hukum Terhadap Masalah-Masalah Sosial, Citra Aditya,Bandung. Hlm 152.

${ }^{19}$ Ahmad Sanusi 1984. Masalah Kesadaran Hukum Dalam Masyarakat Indonesia, Bina Cipta, Jakarta. Hlm 184.

${ }^{20}$ Peter Mahmud Marzuki, Penelitian Hukum, ( Jakarta, Kencana., 2007)., hlm.96.
} 
Data yang hendak dipergunakan dalam penelitian ini, dikategorikan ke dalam data sekunder yang diperoleh melalui bahan-bahan pustaka, yang mencakup (Soerjono Soekanto dan Sri Mamudji, 2011:14):.21

1. Bahan hukum primer, yaitu bahan-bahan hukum yang mengikat dan terdiri dari norma dasar, peraturan dasar, peraturan perundang-undangan, dan bahan hukum yang relevan.

2. Bahan hukum sekunder, yang memberikan penjelasan mengenai bahan hukum primer seperti rancangan undang-undang, hasil-hasil penelitian, dan jurnal ilmiah.

3. Bahan hukum tertier, yakni bahan yang memberikan petunjuk dan penjelasan terhadap bahan hukum primer dan sekunder, seperti kamus dan ensiklopedia.

Teknik pengumpulan data yang dipergunakan adalah studi dokumen atau bahan kepustakaan yaitu penelusuran terhadap dokumen resmi dan tidak resmi sebagai bahan hukum primer dan sekunder untuk memperoleh data sekunder yang relevan yang kemudian akan dijadikan bahan acuan dalam menganalisis permasalahan yang ada. Selain itu, wawancara terstruktur juga dilakukan kepada pihak-pihak yang berkepentingan guna mendapatkan data secara komprehensif.

\section{PEMBAHASAN}

\section{A. Penegakan Hukum Terhadap Pelanggaran Angkutan Jalan Dalam Berlalu Lintas di Kota Ternate.}

Data yang peneliti gunakan untuk mengetahui tingkat pelanggaran lalu lintas maupun kecelakaan lalu lintas di Kota Ternate pada tahun 2018, pelanggaran laulintas seperti tidak memiliki surat-surat kendaraan maupun kelengkapan kendaraan yang telah di atur dalam undang-undang laulintas. Hasil wawancara dengan Bamin Tilang, Brigpol Muhammad Rivan, ${ }^{22}$ menjelaskan bahwa Menurutnya, jenis kendaraan yang dominasi ditilang adalah kendaraan roda dua, dengan jumlah 432 unit sedangkan untuk kendaraan roda empat, Satlantas Polres Ternate mencatat 18 pelangaran tilang bagi pengendara roda empat. Untuk teguran pelanggar lalu lintas angkutan jalan diberikan teguran kepada pengguna jalan sebanyak 372 teguran bagi pengguna kendaraan roda dua maupun pengguna roda empat. Namun ada teguran yang tidak di tilang dan ada teguran disertai dengan tindakan penilangan kepada yang bersangkutan.

Hasil wawancara dengan Kasat Lantas Polres Ternate, AKP Andreas Adi Febrianto, mengatakan bahwa, jenis pelanggaran yang mendominasi adalah helm, yang berjumlah 569, kemudian pelanggaran melawan arus / berlawanan arah sejumlah 48, pengendara di bawah umur berjumlah 37, melebihi batas kecepatan 3, penggunaan lampu iren 21 dan berapa pelanggaran lainya sejumlah 90. Untuk pelanggaran dilihat dari jenis kelamin, laki-laki berjumlah 541 pelanggar dan perempuan berjumlah 259 pelanggar, jika dilihat dari usia pelaku pelanggaran untuk usia 15 tahun itu sejumlah 37 pelanggar. Yang masih di bawah umur, berjumlah 7 orang. Pelanggaran selanjutnya didominasi oleh usia 16 sampai dengan 30 tahun, rata-rata di atas 200 pelanggar.

Kasat Lantas Polres Ternate, AKP Andreas Adi Febrianto, mengatakan bahwa. pihaknya tidak menggunakan metode razia stasioner seperti penggal jalan kemudian dijaga, karena ditakutkan terjadi kemacetan lalu lintas. Sebab jalan di Kota Ternate kecil dan sempit. "Jadi kami patroli ketika ada pelanggaran secara kasat mata, langsung kami lakukan tugas penindakan penilangan ataupun peneguran. Adapun sasaran yang kami cari, sudah ditetapkan pada saat operasi yang di lakukan oleh Sat Lantas, yakni terkait dengan pelanggaran helm

\footnotetext{
21 Soerjono Soekanto dan Sri Mamudji, Poros Pengembangan Hukum Adat, ( Jakarta, Rajawali Pres., 2011)., hlm 14 .

${ }^{22}$ Hasil wawancara dengan Bamin Tilang, Brigpol Muhammad Rivan, Tanggal 15 Mei 2019
} 
yang tidak standar atau yang tidak menggunakan helm. Selain itu, saat berkendara untuk pengendara yang melawan arus, dan pengemudi yang di bawah pengaruh alkohol, pengendara motor di bawa umur, pengendara yang menerobos lampu merah, dan pengendara yang membawa kenderananya melebihi batas kecepatan.

\section{Tabel 2}

Data Pelanggaran Lalu Lintas Kota Ternate Tahun 2018

\begin{tabular}{|c|c|c|c|c|c|}
\hline No & $\begin{array}{l}\text { Jenis } \\
\text { Pelanggaran }\end{array}$ & $\begin{array}{l}\text { Jenis } \\
\text { Kendaraan }\end{array}$ & $\begin{array}{l}\text { Jumlah } \\
\text { Pelanggaran }\end{array}$ & $\begin{array}{l}\text { Jumlah } \\
\text { Teguran }\end{array}$ & $\begin{array}{l}\text { Jumlah } \\
\text { Tilang }\end{array}$ \\
\hline 1 & $\begin{array}{l}\text { Tidak Menggunakan } \\
\text { Helm }\end{array}$ & Roda Dua & 569 & 276 & 569 \\
\hline 2 & Berlawanan Arah & Roda Dua & 48 & 48 & - \\
\hline 3 & $\begin{array}{l}\text { Berkendara dibawah } \\
\text { Umur }\end{array}$ & Roda Dua & 37 & 24 & 37 \\
\hline 4 & Melebihi Batas Kecepatan & Roda Dua & 3 & 3 & - \\
\hline 5 & Penggunaan Lampu iren & Roda Dua & 21 & 21 & - \\
\hline 6 & $\begin{array}{l}\text { Memasuki } \\
\text { Larangan }\end{array}$ & Roda Dua & 19 & - & 19 \\
\hline 7 & $\begin{array}{ll}\text { Memasuki } & \text { Tanda } \\
\text { Larangan }\end{array}$ & $\begin{array}{l}\text { Roda } \\
\text { Empat }\end{array}$ & 17 & - & 17 \\
\hline 8 & $\begin{array}{l}\text { Tidak Memiliki Surat- } \\
\text { Surat Kendaraan }\end{array}$ & Roda Dua & 14 & - & 14 \\
\hline 9 & $\begin{array}{l}\text { Tidak Memiliki Surat- } \\
\text { Surat Kendaraan }\end{array}$ & $\begin{array}{l}\text { Roda } \\
\text { Empat }\end{array}$ & 8 & - & 8 \\
\hline 10 & $\begin{array}{ll}\text { Tidak Memiliki Kaca } \\
\text { Spion }\end{array}$ & Roda Dua & 6 & - & 6 \\
\hline 11 & $\begin{array}{l}\text { Tidak Memiliki Lampu } \\
\text { Depan }\end{array}$ & Roda Dua & 5 & - & 5 \\
\hline \multicolumn{2}{|c|}{ Total } & & 747 & 372 & 675 \\
\hline
\end{tabular}

Sumber : Polres Ternate, Bagian SAT

Tahun 2018 terjadi 95 kasus lakalantas, dengan total kerugian material Rp. 214.625 .000 (dua ratus empat belas juta enam ratus dua puluh lima ribu rupiah), korban dari akibat lakalantas yang mengakibatkan meninggal dunia sebanyak 16 orang, yang luka berat 49 orang dan yang luka ringan 27 orang, semua kasus lakalantas pada tahun 2018 telah inkrah karena telah diproses secara hukum yang telah mempunyai ketetapan hukum. Untuk lebih jelasnya dapat dilihat pada tabel di bawah ini : 
Tabel 3.

Data Lakalantas Serta Kerugian Material Tahun 2018

\begin{tabular}{|c|c|c|c|c|c|c|c|c|}
\hline \multirow{2}{*}{ No } & \multirow{2}{*}{ Bulan } & \multirow{2}{*}{$\begin{array}{l}\text { Jml } \\
\text { Kasus }\end{array}$} & \multicolumn{3}{|c|}{ Akibat } & \multirow{2}{*}{$\begin{array}{l}\text { Kerugian } \\
\text { Material (Rp) }\end{array}$} & \multicolumn{2}{|c|}{ Proses Hukum } \\
\hline & & & MD & LB & LR & & Selesai & Belum \\
\hline 1 & Januari & 23 & 9 & 13 & 1 & 31.500 .000 & Selesai & - \\
\hline 2 & Februari & 12 & 1 & 7 & 4 & 33.400 .000 & Selesai & - \\
\hline 3 & Maret & 13 & 1 & 6 & 6 & 24.200 .000 & Selesai & - \\
\hline 4 & April & 10 & 1 & 3 & 4 & 13.975 .000 & Selesai & - \\
\hline 5 & Mei & 3 & 0 & 3 & 0 & 19.000 .000 & Selesai & - \\
\hline 6 & Juni & 10 & 0 & 7 & 1 & 29.500 .000 & Selesai & - \\
\hline 7 & Juli & 6 & 2 & 4 & 0 & 1.800 .000 & Selesai & - \\
\hline 8 & Agustus & 4 & 1 & 2 & 0 & 8.900 .000 & Selesai & - \\
\hline 9 & $\begin{array}{l}\text { Septembe } \\
\mathrm{r}\end{array}$ & 4 & 1 & 3 & 0 & 16.100 .000 & Selesai & - \\
\hline 10 & Oktober & 1 & 0 & 0 & 1 & 1.500 .000 & Selesai & - \\
\hline 11 & Nopember & 8 & 0 & 0 & 8 & 19.250 .000 & Selesai & - \\
\hline 12 & Desember & 1 & 0 & 1 & 2 & 15.500 .000 & Selesai & - \\
\hline \multicolumn{2}{|c|}{ Total } & 95 & 16 & 49 & 27 & 214.625.000 & 12 & 0 \\
\hline
\end{tabular}

Sumber : Polres Ternate, Bagian SAT

Keterangan :

MD : Meninggal Dunia

LB : Luka Berat

LR : Luka Ringan

Perkara pelanggaran lalu lintas di Kota Ternate, harus segera ditindaki sesuai dengan peraturan perundang-undangan yang berlaku, karena aksi penegakan supremasi hukum terhadap pelanggaran lalu lintas akan dapat mengikat dan menimbulkan efek jera terhadap pengendara kendaraan bermotor (Ranmor) untuk mematuhi peraturan lalu lintas. Kasat Lantas Polres Ternate, AKP Andreas Adi Febrianto, menjelaskan bahwa Perkara tilang diadili dengan acara pemeriksaan cepat dan tidak dapat diadili dengan cara pemeriksaan biasa, tetapi walaupun menggunakan pemeriksaan cepat SAT LANTAS Polres Ternate dalam menerapkannya, tetap menggunakan atau tidak keluar dari koridor Kitab Undang-Undang Hukum Acara Pidana (KUHAP). Sistim peradilan tilang lembaga yang terlibat sebagai subsistim adalah kepolisian, kejaksaan dan pengadilan dengan tugas dan fungsinya yang telah diatur sesuai dengan UU. ${ }^{23}$

\footnotetext{
${ }^{23}$ Wawancara Kasat Lantas Polres Ternate, AKP Andreas Adi Febrianto, Tanggal 14 Mei 2019
} 
Disamping itu Polres Ternate juga mempunyai Standar Operasional Prosedur (SOP) terhadap penindakan lalu lintas seperti yang telah diatur dalam Peraturan Kapolres Ternate Nomor 02/IV/2012 Tentang Standar Operasional Prosedur (SOP). ${ }^{24}$ Secara umum hukum acara yangdilakukan terhadap pelanggaran lalu lintas ketika terjadi tilang atau tindak pidana ringan, SAT LANTAS Polres Ternate tidak memerlukan Berita Acara Pemeriksaan (BAP), penyidik SAT LANTAS hanya mengirimkan catatan-catatan atau formulir (balanko) tilang ke Pengadilan Negeri (PN) Ternate. Hal ini sesuai dengan Pasal 212 KUHAP, yang menyatakan "untuk perkara pelanggaran lalu lintas jalan tidak diperlukan Berita Acara Pemeriksaan, oleh karena itu catatan sebagaimana dimaksud dalam Pasal 207 ayat (1) huruf a segera diserahkan kepada pengadilan selambat-lambatnya pada kesempatan hari sidang pertama berikutnya". Dan Pasal 207 ayat (1a) KUHAP yang menyatakan bahwa,"Penyidik memberitahukan secara tertulis kepada Terdakwa tentang hari, tanggal, jam dan tempat ia harus menghadap sidang pengadilan dan hal tersebut dicatat dengan baik oleh penyidik, selanjutnya catatan bersama berkas dikirim ke pengadilan". Blanko yang dipergunakan oleh kepolisian berupa buku, satu set terdiri dari 4 (empat) lembar dan mempunya masing-masing warna sesuai dengan fungsi masing-masing antara lain :

a. Merah dipergunakan Tersangka

b. Kuning dipergunakan untuk satuan setingkat di atas

c. Putih dpergunakan untuk Pengadilan Negeri Ternate

d. Biru dipergunakan untuk Kejaksaan Negeri Ternate

Penggunaan blangko tilang yang diberikan Penyidik kepada Terdakwa pelanggar lalu lintas sebagai bukti pelanggaran lalu lintas tertentu, dan merupakan perintah/eksekusi Pengadilan Negeri atau setoran uang titipan ke Bank. Balanko tilang memuat 27 (dua puluh tujuh pelanggaran lalu lintas.

a. Hakim yang memimpin persidangan ini adalah hakim tunggal seperti yang diatur dalam Pasal 205 ayat (3) KUHAP yang menyatakan "dalam acara pemeriksaan sebagaimana dimaksud dalam ayat (1), pengadilan mengadili dengan Hakim Tunggal pada tingkat pertama dan terakhir, kecuali dalam hal dijatuhkan pidana perampasan kemerdekaan terdakwa dapat minta banding.

b. Di dalam sidang pemeriksaan perkara tilang terdakwa boleh tidak hadir dan dapat menunjuk seseorang untuk mewakilinya di persidangan, dalam hal ini pemeriksaan perkara tetap dilanjutkan dan diputus dengan putusan verstek. Seperti yang diatur dalam Pasal 213 KUHAP yang menyatakan "Terdakwa dapat menunjuk seorang dengan surat untuk mewakilinya di sidang". Dan Pasal 214 ayat (1) yang menyatakan "jika terdakwa atau wakilnya tidak hadir di sidang, pemeriksaan perkara dilanjutkan".

c. Perkara tilang tidak ada surat tuduhan atau gugatan dan tidak adanya putusan tersendiri yang lepas dari berkas perkara, putusan hakim tercantum dalam berita acara sidang artinya disambungkan pada berita acara tersebut. seperti maksud dari Pasal 203 ayat (3d) yang menyatakan "putusan tidak dibuat secara khusus, tetapi dicatat dalam berita acara sidang".

d. Putusan denda dari pengadilan berbeda-beda tergantung putusan hakim.

Peneliti mengadakan penelitian di Pengadilan Negeri Ternate, tertanggal 14 Mei-27 Juni 2019 data yang peneliti input adalah penetapan putusan hakim dalam proses pemeriksaan cepat terhadap pelanggaran lalu lintas antara tahun 2018 sampai dengan 2019. Pada bulan Januari

24 Peraturan Kapolres Ternate Nomor 01/III/2012 Tentang Standar Operasional Prosedur Pengaturan, Penjagaan, Pengawalan, dan Patroli (TURJAWALI Lantas) 
sampai dengan Desember 2018 ada 5257 perkara yang masuk ke Pengadilan Negeri Ternate dan sebanyak 5257 Perkara yang telah di tetapkan/diputus oleh Hakim. Hal ini dapat dilihat pada Tabel 11 di bawah ini :

\section{Tabel 5}

Perkara Pemeriksaan Cepat Pelanggaran Lalu Lintas Di Pengadilan Negeri Ternate Januari s/d Bulan Desember Tahun 2018.

\begin{tabular}{|l|l|l|l|}
\hline Bulan & $\begin{array}{l}\text { Perkara } \\
\text { Masuk }\end{array}$ & $\begin{array}{l}\text { Perkara } \\
\text { Diputus }\end{array}$ & Sisa Perkara \\
\hline Januari & 230 & 230 & - \\
\hline Februari & 290 & 290 & - \\
\hline Maret & 210 & 210 & - \\
\hline April & 272 & 272 & - \\
\hline Mei & 281 & 281 & - \\
\hline Juni & 293 & 293 & - \\
\hline Juli & 300 & 300 & - \\
\hline Agustus & 330 & 330 & - \\
\hline Septem. & 372 & 372 & - \\
\hline Oktober & 350 & 350 & - \\
\hline Nopem. & 390 & 390 & - \\
\hline Desemb & 403 & 403 & - \\
\hline Total & $\mathbf{5 2 5 7}$ & $\mathbf{5 2 5 7}$ & - \\
\hline
\end{tabular}

Pada bulan Januari sampai dengan Desember 2018 ada 3721 perkara yang masuk ke Pengadilan Negeri Ternate dan sebanyak 3721 Perkara yang telah di tetapkan/diputus oleh Hakim. Hal ini dapat dilihat pada Tabel 10 di bawah ini :

Tabel 6.

Perkara Pemeriksaan Cepat Pelanggaran Lalu Lintas Di Pengadilan Negeri Ternate Bulan Januari s/d Bulan Desember Tahun 2018.

\begin{tabular}{|l|l|l|l|}
\hline Bulan & $\begin{array}{l}\text { Perkara } \\
\text { Masuk }\end{array}$ & $\begin{array}{l}\text { Perkara Yg } \\
\text { Diputus }\end{array}$ & $\begin{array}{l}\text { Sisa } \\
\text { Perkara }\end{array}$ \\
\hline Januari & 230 & 230 & - \\
\hline Februari & 290 & 290 & - \\
\hline Maret & 210 & 210 & - \\
\hline April & 272 & 272 & - \\
\hline Mei & 281 & 281 & - \\
\hline Juni & 293 & 293 & - \\
\hline Juli & 300 & 300 & - \\
\hline Agustus & 330 & 330 & - \\
\hline September & 372 & 372 & - \\
\hline Oktober & 350 & 350 & - \\
\hline Nopember & 390 & 390 & - \\
\hline Desember & 403 & 403 & - \\
\hline Total & $\mathbf{3 7 2 1}$ & $\mathbf{3 7 2 1}$ & - \\
\hline Sumber Penglin Neger Terne Tahun 2019
\end{tabular}

Sumber Pengadilan Negeri Ternate Tahun 2019 
Pada bulan April 2018 ada 808 perkara yang masuk ke Pengadilan Negeri Ternate dan sebanyak 808 Perkara yang telah di tetapkan/diputus oleh Hakim. Hal ini dapat dilihat pada Tabel 9 di bawah ini :

\section{Tabel 7}

Perkara Pemeriksaan Cepat Pelanggaran Lalu Lintas Di Pengadilan Negeri Ternate Sampai Bulan April Tahun 2018.

\begin{tabular}{|l|l|l|l|}
\hline Bulan & $\begin{array}{l}\text { Perkara } \\
\text { Masuk }\end{array}$ & $\begin{array}{l}\text { Perkara Yg } \\
\text { Diputus }\end{array}$ & Sisa Perkara \\
\hline Januari & 233 & 233 & - \\
\hline Februari & 140 & 140 & - \\
\hline Maret & 276 & 276 & - \\
\hline April & 159 & 159 & - \\
\hline Total & $\mathbf{8 0 8}$ & $\mathbf{8 0 8}$ & - \\
\hline
\end{tabular}

Sumber Pengadilan Negeri Ternate Tahun 2019

\section{1) Pemeriksaan Perkara Laka Lantas}

Berdasarkan hasil wawancara dengan AIPTU Mhd. Rusli Fatmona yang menjabat sebagai KANIT LAKA pada tanggal 18 Juni 2013 mengatakan bahwa Polres Ternate selalu siaga apabila terjadi laka lantas tindakan pertama yang kami ambil adalah sesuai dengan SOP yang menjadi pegangan kami terutama yang diatur dalam Pasal 9 ayat (5) Peraturan Kapolres Ternate Nomor 02/IV/2012 Tentang Standar Operasional Prosedur (SOP).

Pada prinsipnya apabila terjadi laka lantas disebabkan oleh human error yang mengikabatkan korban apalagi sampai meninggal dunia, maka kejadian dari laka lantas ini adalah Tindak Pidana Umum, yang prosesnya harus sesuai dengan Hukum Acara Pidana yang berlaku.

Peneliti mengadakan penelitian di Pengadilan Negeri Ternate, pada tanggal 14 Mei-27 Juni 2019, data yang peneliti input adalah jumlah kasus dalam proses pemeriksaan perkara oleh Majelis Hakim yang diakibatkan oleh lakalantas dan termasuk pidana umum. Perkara yang telah di putuskan oleh Majelis Hakim dan in cracht yang telah mempunyai kekuatan hukum tetap, antara tahun 2018 sampai dengan 2019, pada tahun 2018 perkara yang masuk di Pengadilan negeri Ternate adalah sebanyak 221 perkara yang merupakan akumulasi dari perkara pada tahun 2017 yang lalu, perkara yang telah diputus pada tahun 2018 sebanyak 149 perkara dan sisa perkara yang belum diputus adalah sebanyak 72 perkara. Pada tahun 2019 perkara yang masuk di Pengadilan Negeri Ternate sebanyak 296 perkara yang merupakan akumulasi dari perkara tahun 2018 yang belum diputus, perkara yang diputus pada tahun 2019 sebanyak 214 perkara dan sisa perkara yang belum diputus adalah sebanyak 82 perkara. Pada tahun 2019 data yang peneliti peroleh hanya dari bulan januari sampai pada bulan April 2019, perkara yang masuk di pengadilan Negeri Ternate sebanyak 165 perkara yang merupakan akumulasi dari perkara yang belum diputus pada tahun 2018, perkara yang sudah diputus adalah sebanyak 79 perkara, dan yang belum diputus adalah sebanyak 86 perkara. Untuk lebih jelasnya dapat dilihat pada tabel 12 dibawah ini : 
Tabel 9

Jumlah Perkara Tindak Pidana Biasa Di Wilayah Hukum Pengadilan Negeri Ternate

\begin{tabular}{|c|c|c|c|}
\hline Tahun & $\begin{array}{c}\text { Perkara } \\
\text { Masuk }\end{array}$ & $\begin{array}{c}\text { Perkara Yg } \\
\text { Diputus }\end{array}$ & $\begin{array}{c}\text { Sisa } \\
\text { Perkara }\end{array}$ \\
\hline 2018 & 221 & 149 & 72 \\
\hline 2019 & 296 & 214 & 82 \\
\hline 2019 & 165 & 79 & 86 \\
\hline Total & $\mathbf{6 8 2}$ & $\mathbf{4 4 2}$ & $\mathbf{2 4 0}$ \\
\hline
\end{tabular}

Sumber Pengadilan Negeri Ternate Tahun 2018-2019

\section{B. Faktor-faktor Yang Mempengaruhi Penegakan Hukum Terhadap Penyelesaian Perkara Lakalantas di Luar Pengadilan.}

Fenomena yang sering terjadi apabila terjadi laka lantas di Kota Ternate adalah antara pelaku maupun korban ada penyelesaian mempergunakan jalur perdamaian, tetapi tindakan itu dapat dilakukan apabila tidak menimbulkan korban jiwa, hanya mengakibatkan kerugian materiil atau harta benda, karena pada prinsipnya setiap perkara laka lantas yang sampai menimbulkan korban meninggal dunia adalah merupakan perkara pidana yang harus diselesaikan di pengadilan, seperti kutipan hasil wawancara peneliti dengan Bpk. Rusli Fatmona yang menjabat sebagai KANIT LAKA Polres Ternate pada hari Selasa bertempat di Polres Ternate Bagian SAT LANTAS pada tanggal 18 Juni 2013, yang mengatakan bahwa, "memang fenomena penyelasaian secara damai sering terjadi, dan kebanyakan dari pelaku maupun korban meminta pihak kepolisian untuk memfasilitasinya, tetapi hanya dalam hal kasus laka lantas yang menimbulkan kerugian material harta benda dan kerusakan kendaraan. Dalam hal penyelesaian secara kekeluargaan dapat dijadikan solusi supaya tidak berdampak/menimbulkan masalah baru seperti perkelahian dan lain-lain, selagi kedua belah pihak sepakat untuk hal ganti rugi dan diketahui oleh Kepala Desa/Lurah dan pihak kepolisisan setempat, kemudian dibuat surat pernyataan dari kedua belah pihak. Namun jika kedua belah pihak tidak ada kesepakatan penyelesaian secara kekeluargaan maka di proses secara hukum sesuai dengan peraturan perundang-undangan yang berlaku".

Adapun yang dimaksud penyelesaian diluar sidang pengadilan adalah penyelesaian perkara secara kekeluargaan yaitu antara pelaku dengan keluarga korban untuk melakukan perdamaian. Dalam praktek polisi sebagai penyidik khususnya dalam menangani perkara laka lantas yang menyebabkan luka-luka maupun meninggal dunia pada diri orang lain dapat menerima penyelesaiannya dilakukan diluar pengadilan meskipun perkara tersebut termasuk Tindak Pidana Umum. Hasil wawancara peneliti dengan Panitera Muda Pidana Umum Pengadilan Negeri Ternate pada tanggal 19 Juni 2013 menyatakan "bahwa laka lantas yang mengakibatkan korban jiwa luka ringan maupun luka berat, pelaku harus bertanggung jawab atas perbuatannya apalagi sampai korban meninggal dunia, karena kejadian tersebut termasuk tindak pidana umum dan ini bukan delik aduan yang bisa dibatalkan dalam hal penuntutan maka Penyidik harus melakukan proses hukum acara sesuai dengan peraturan perundangundangan yang berlaku". Kejadian laka lantas adalah suatu perbuatan manusia dimana akan bergesekan dengan kepentingan dan eksistensi suatu negara, maka apakah dimungkinkan jalur damai ini dapat menggugurkan tuntutan, dijelaskan kembali oleh KANIT LAKA Polres Ternate berdasarkan hasil wawancara pada tanggal 18 Juni 2013 menyatakan bahwa "menurut saya jalur perdamaian dalam perkara laka lantas tidak mengugurkan tuntutan karena demi asas keadilan/pro justisia". 
Pengemudi atau pelaku juga harus bertanggung jawab kepada korban apabila korban meninggal dunia karena sesuai dengan Pasal 235 ayat (1) huruf c UU No. 22 Tahun 2009 yang menyebutkan "Pengemudi, pemilik, dan/atau Perusahaan Angkutan Umum wajib memberikan bantuan kepada ahli waris korban berupa biaya pengobatan dan/atau biaya pemakaman dengan tidak menggugurkan tuntutan perkara pidana". Tetapi setiap pengemudi yang karena kelalaiannya mengakibatkan kecelakaan lalu lintas wajib bertanggung jawab atas kerugian yang diderita korban, akan tetapi tanggung jawab ini tidak berlaku apabila seperti yang diatur dalam Passal 234 ayat 3 UU No. 22 Tahun 2009 yang menyebutkan :

a. adanya keadaan memaksa yang tidak dapat dielakkan atau di luar kemampuan pengemudi;

b. disebabkan oleh perilaku korban sendiri atau pihak ketiga; dan/ atau

c. disebabkan gerakan orang dan/ atau hewan walaupun telah diambil tindakan pencegahan.

Berdasarkan ketentuan di atas, dapat diketahui bahwa walaupun pengemudi telah bertanggung jawab atas kematian korban, tuntutan pidana terhadap dirinya tidak menjadi hilang. Oleh karena itu, kepolisian tetap melakukan penyidikan sesuai hukum acara pidana sesuai peraturan perundang-undangan seperti yang termaktub dalam Pasal 230 UU No. 22 Tahun 2009. Dan Ancaman sanksi pidana untuk pengemudi Ranmor penyebab kecelakaan lalu lintas yang mengakibatkan korban meninggal dunia adalah pidana penjara paling lama 6 tahun dan/atau denda paling banyak Rp12.000.000, seperti yang diatur dalam Pasal 310 ayat (4) UU No. 22 Tahun 2009.

Menurut analisa peneliti secara kontekstual penyelesaian perkara diluar pengadilan sangat mempengaruhi penegakan hukum laka lantas di Kota Ternate, ada batasan-batasan yang menjadi ukuran untuk melakukannya selama tidak bertentangan dengan prinsip-prinsip hukum acara pidana yang berlaku. Secara garis besar timbulnya penyelesaian perkara laka lantas yang tidak melalui jalur pengadilan di Kota Ternate disebabkan karena beberapa faktor antara lain :

1. Pelaku ingin menghindari proses tindak pidana yang akan dijatuhkan oleh Majelis Hakim, karena pola pikir masyarakat Kota Ternate yang menganggap bahwa orang yang terlibat dalam suatu tindak pidana yang telah divonis oleh pengadilan adalah orang yang tercela.

2. Keluarga korban menerima kejadian itu sebagai suatu mushibah atau ujian sehingga membuka ruang untuk mengadakan penyelesaian secara kekeluargaan, berupa penggantian biaya-biaya yang dikeluarkan untuk korban, dan sejumlah uang kompensasi.

3. Aparat penegak hukum yang memberikan pembenaran terhadap bentuk penyelesaian seperti itu.

Penegakan hukum harus ditegakkan secara konsiten agar legitimasi terhadap keadilan menjadi sangat berarti dan berwibawa, penyelesaian suatu perkara pidana tanpa melalui proses hukum yang berlaku akan sangat berpengaruh terhadap eksistensi suatu negara, karena dengan adanya hukum merupakan suatu nilai atau kaidah yang mengatur kehidupan sosial dalam masyarakat agar tidak terjadi gesekkan kepentingan demi mewujudkan suatu keadilan yang bermartabat.

\section{KESIMPULAN}

Sebagai akhir dari tulisan ini, maka dapat diambil kesimpulan bahwa Proses penegakan hukum terhadap laka lantas di Kota Ternate, sudah sesuai dengan KUHAP, dalam perkara lakalantas bagi pelaku yang diduga menjadi tersangka di proses sesuai Hukum Acara dalam Tindak Pidana Umum. Dalam perkara pelanggaran lalu lintas di Kota Ternate proses 
penyelesaiannya menggunakan penyelesaian secara cepat, tidak menggunakan BAP penyidik tetapi hanya menggunakan catatan-catatan atau blangko dari kepolisian sebanyak empat rangkap yang terdiri dari merah dipergunakan untuk Tersangka, putih untuk pengadilan, biru untuk kejaksaan, kuning untuk satuan setingkat di atas dan dalam persidangan di Pengadilan Negeri Ternate Tersangka maupun jaksa tidak diharuskan untuk menghadiri persidangan, Hakim yang memimpin persidangan pelanggaran lalu lintas adalah hakim tunggal. Faktorfaktor yang mempengaruhi penegakan hukum terhadap laka lantas adalah penyelesaian diluar pengadilan atau dengan cara kekeluargaan apabila terjadi kesepakatan dan perkara ini tidak di proses sesuai hukum acara yang berlaku dan akan menggugurkan tuntutan.

\section{DAFTAR PUSTAKA}

Ahmad Sanusi 1984. Masalah Kesadaran Hukum Dalam Masyarakat Indonesia, Bina Cipta, Jakarta.

Kosasih Djahiri, 1985. Strategi Pengajaran Afektif Nilai-Nilai Moral, ISIP, Bandung.

Peter Mahmud Marzuki, Penelitian Hukum, ( Jakarta, Kencana., 2007).

Poerwadarminta,1987. Kamus Umum Besar Bahasa Indonesia,Balai Pustaka, Jakarta.

Soerjono Soekanto dan Sri Mamudji, Poros Pengembangan Hukum Adat, ( Jakarta, Rajawali Pres., 2011).

Soerjono Soekanto, 1982. Suatu Tinjauan Sosiologi Hukum Terhadap Masalah-Masalah Sosial, Citra Aditya,Bandung.

Soerjono Soekanto, 2011. Faktor-Faktor Yang Mempengaruhi Penegakan Hukum, Cet. Kesepuluh, Raja Grafindo Persada, Jakarta.

Sudikno Mertokusumo, 1984, Bunga Rampai Ilmu Hukum, Liberty, Yogyakarta.

Soerjono Soekanto, 1987, Pendekatan Sosiologi Terhadap Hukum, Jakarta, Bina Aksara.

Tim Redaksi Pustaka Yustisia, 2010, UU No. 22 Tahun 2009 Tentang lalu Lintas dan Angkutan Jalan, Jakarta.

Maxtry Parante https://media.neliti.com/media/publications/115374-ID-peranan-kepolisianlalu-lintas-dalam-pen.pdf 